\title{
Chronic Thromboembolic Pulmonary Hypertension: Effects of Pulmonary Endarterectomy
}

\author{
Coen van Kan'1, Mart N. van der Plas', Jaap J. Kloek², \\ Herre J. Reesink ${ }^{1}$ and Paul Bresser ${ }^{1,2}$ \\ ${ }^{1}$ Department of Respiratory Medicine, Onze Lieve Vrouwe Gasthuis, \\ 2Department of Cardiothoracic Surgery, Academic Medical Center, \\ University of Amsterdam, Amsterdam, \\ The Netherlands
}

\section{Introduction}

Chronic thromboembolic pulmonary hypertension (CTEPH) results from incomplete resolution of the vascular obstruction associated with pulmonary embolism (PE) (Fedullo et al., 2001; Hoeper et al., 2006). This condition is considered to develop in 1-4 \% of patients who survive an acute pulmonary embolism (Becattini et al., 2006; Fedullo et al., 2001; Pengo et al., 2004). Given the worldwide incidence of acute PE, approximately 1:1000, this indicates that even in a small country like the Netherlands, CTEPH may be diagnosed in up to 600 patients yearly.

Most CTEPH patients present with gradually progressive exercise intolerance, typically portrayed as exertional dyspnea, fatigue, palpitations and/or on productive cough. In further stages of disease there may be signs of right ventricular failure, chest pain on exertion and syncope. The ensuing progressive right ventricular failure leads to progressive disability and early death ( Hoeper et al., 2004) .

If left untreated, CTEPH is a progressive and life-threatening disorder; survival being proportional to the degree of pulmonary hypertension at diagnosis. In CTEPH patients with a mean pulmonary arterial pressure (mPAP) above $30 \mathrm{mmHg}$ at time of diagnosis, 5-years survival is about $30 \%$, whereas in patients with a mPAP above $50 \mathrm{mmHg}$ the 5-years survival may be as low as $10 \%$ (Lewczuk et al., 2001; Riedel et al., 1982). Pulmonary endarterectomy (PEA) is the therapy of first choice for CTEPH patients with surgical accessible thrombi (Fedullo et al., 2001; Jamieson et al., 2000, 2003). PEA has been found to improve, and in many cases normalize pulmonary hemodynamics, functional status and long-term survival. PEA, however, does not come without potential risk. Reported peri- and direct postoperative mortality still ranges between $4.4 \%$ and $16 \%$ even in experienced centres (Archibald et al., 1999; Auger et al., 2007; Condliffe et al., 2008; Jamieson et al., 2000 ; Rubens et al., 2007).

In this chapter we will discuss the pathophysiology of CTEPH. In particular, we will focus on the pathophysiology of the exercise limitation and dyspnea that is observed in these patients. Moreover, the effects of surgical treatment, that is the removal of the obstructing chronic thrombi by pulmonary endarterectomy, on cardiac function and the restoration of exercise tolerance and dyspnea will be discussed. 


\section{Pathophysiology of CTEPH}

Pulmonary hypertension $(\mathrm{PH})$ in general is a progressive and life-threatening disorder. It is pathophysiologically characterized by a gradually progressive increase in the pulmonary vascular resistance. As a consequence, in order to maintain an adequate transpulmonary blood flow, the pulmonary artery pressure will increase. The definition of $\mathrm{PH}$ is based on right heart catheterisation measurements; and $\mathrm{PH}$ was classically defined as a mean pulmonary artery pressure (mPAP) greater than $25 \mathrm{mmHg}$ at rest or $30 \mathrm{mmHg}$ during exercise. Recently, however, inclusion of exercise-induced $\mathrm{PH}$ in the definition has been the subject of debate, leading to it's exclusion from the most recent guidelines (Kovacs et al., 2009; Galie et al., 2009). In CTEPH, pulmonary hypertension is considered to be primarily the result of the anatomic loss of pulmonary vascular bed due to the irreversible chronic thromboembolic obstruction. However, the pathophysiology of the disease appears far more complex. Pneumonectomy, for instance, is associated with little, if any, increase in pulmonary artery pressure, even with follow-up to 11 years (Cournand et al., 1950; Smulders et al., 2007). Experimental studies have even indicated that up to a $75 \%$ reduction in lung volumes does not cause pulmonary hypertension (Harrison et al., 1957). Nevertheless significant pulmonary hypertension at rest can be observed in CTEPH patients with relatively minor chronic thromboembolic obstruction of the pulmonary vasculature (Jamieson et al., 2000). This indicates that factors other than simple hemodynamic consequences of redirected blood flow are likely to be involved in the pathophysiology of CTEPH.

Concepts of pathogenesis and progression of the disease after the initial pulmonary embolus involve both recurrent thromboemboli and failure to resolve the acute thromboemboli. In the past, abnormalities in coagulation and fibrinolysis pathways have been identified in CTEPH patients, however, the frequency of these defects in such patients were similar to those in the general population. Lupus anticoagulant and antiphospholipid antibodies were shown to be present in $10-20 \%$ of patients with CTEPH, which is higher than in patients with acute venous thromboembolism (Auger et al., 1995; Wolf et al., 2000). Bonderman et al. showed increased levels of factor VIII (FVIII) in about $40 \%$ of CTEPH patients as compared to both healthy controls and patients with non-thromboembolic pulmonary hypertension (Bonderman et al., 2003). FVIII is a well recognised risk factor for single (O'Donnell et al., 1997) and, in particular, recurrent venous thromboembolism (Kyrle et al., 2000). Furthermore, inherited deficiencies of protein C, protein S and anti-thrombin III were identified in 1-5\% of patients (Colorio et al., 2001; Moser et al., 1990). Moreover, other risk factors have been identified in the development of $\mathrm{CTEPH}$, including chronic inflammatory disorders, myeloproliferative syndromes, ventriculo-atrial drains, a history of pacemaker infection, thyroid disease and replacement therapy, and splenectomy (Bonderman et al., 2005, 2009; Jais et al., 2005).

Over time, a gradual hemodynamic and symptomatic decline can be observed in CTEPH patients. Progression of disease may be the consequence of recurrent thromboembolism or in situ pulmonary artery thrombosis. Hemodynamic progression, however, can also be observed in patients without evidence of recurrent thromboembolism, while using adequate oral anticoagulant treatment. Taken together, this indicates that a second pathobiological process is likely to be involved (Lang, 2010). The current understanding is that a hemodynamically significant persistent obstruction of the pulmonary arteries may result in an elevated pulmonary artery pressure and high shear stress in areas which are spared from occlusion; this in combination with a concomitant inflammation, and an imbalance of vasoactive mediators may result in the vascular remodelling that is observed in these 
patients (Bauer et al., 2002; Humbert et al., 2004 Humbert et al., 2004; Reesink et al., 2006; Hoeper et al., 2004; Lang, 2010). Histopathologic changes in the microvasculature, similar to those demonstrated in other forms of pulmonary arterial hypertension (PAH), were observed in lung biopsy specimens from CTEPH patients (Moser et al., 1973). The development of this slowly progressive secondary arteriopathy in the non-obstructed precapillary pulmonary vessels is likely the cause of the progression of disease that can be observed in CTEPH patients (Fedullo et al., 2011; Hoeper et al., 2006; Lang, 2010). By contributing to the elevated pulmonary vascular resistance, this arteriopathy adversely affects cardiac function and may, in the end, contribute to the progressive hemodynamic instability and increased mortality observed in patients with CTEPH (Riedel et al., 1982).

Advanced CTEPH leads to cardiac remodelling, as characterized by right ventricular (RV) dilatation and hypertrophy, tricuspid regurgitation and leftward ventricular septal bowing (LVSB), with a consequent impact on cardiac function (Fleg et al., 2000; Groepenhoff et al., 2008; Kreitner et al., 2007, 2004; Reesink et al., 2007). We have shown that LVSB is present in the majority of CTEPH patients (Reesink et al., 2007). Early diastolic septal bowing is an ominous sign in patients with pulmonary hypertension. During systole, the pressure in left ventricle (LV) normally exceeds the RV pressure, showing a (positive) curvature away from the LV centre. During early LV diastole, the LV pressure drops to near zero to enable rapid LV filling. The increased RV pressure pushes the septum away from the from the RV centre, causing (negative) LVSB (Marcus et al., 2001). We have shown that the interventricular septal bowing correlates with the severity of pulmonary hypertension in CTEPH patients (Reesink et al., 2007). So, although RV dysfunction is most outspoken, also LV function is significantly impaired these patients. The impairment of the LV function might be attributable to ventricular interaction or ventricular interdependence (also known as the "reversed Bernheim phenomenon"): RV dilatation and hypertrophy shift the interventricular septum leftward, thereby causing decreased LV cavity size, contractility, compliance, and ejection fraction (Alpert et al., 2001). LV diastolic dysfunction, however, may also be caused in part by myocardial hypertrophy of the RV and interventricular septum, as documented in both patients with CTEPH and idiopathic pulmonary arterial hypertension (iPAH) (Hardziyenka et al., 2011; Marcus et al., 2001; Reesink et al., 2007). In iPAH, it was shown that ventricular interaction mediated by interventricular septum bowing caused an impairment of the LV filling and thereby contributed to the decreased stroke volume observed in these patients (Gan et al., 2006). We have recently shown that in (CTE)PH patients also atrophy of the LV free wall may contribute to the impairment of the LV function. In a rat model of right ventricular failure due to pulmonary hypertension, we showed that reduction in LV free wall mass can be, at least in part, explained by myocyte shrinkage due to atrophic remodelling associated with left ventricle underfilling (Hardziyenka et al., 2011).

\section{Pathophysiology of exercise limitation in CTEPH patients}

In CTEPH, as in pulmonary hypertension in general, exercise is primarily limited by the impairment of cardiac function. As discussed, advanced pulmonary hypertension in CTEPH leads to chronic RV volume overload, cardiac remodelling and dysfunction. The limitation in exercise capacity is in major part caused by the inability of the heart to sufficiently increase pulmonary blood flow due to a decreased RV stroke volume response during exercise (Raeside et al., 2000; Holverda et al., 2006). 
Normally, upon exercise cardiac output is elevated by increasing heart rate, stroke volume or both. When stroke volume increases, pulmonary blood flow will increase; pulmonary arterial pressure, however, will not significantly increase due to pulmonary vascular dilatation and recruitment (Bonderman et al., 2011). In PH, however, these mechanisms of lowering pulmonary vascular resistance are lost due to the secondary arteriopathy in the pre-capillary pulmonary vessels. As a result, the pulmonary pressure will rise in order to maintain pulmonary blood flow with a subsequent effect on stroke volume upon exercise. The exerciseassociated increase in pulmonary arterial pressure will result in further impairment of RV function, as well as LV underfilling, both leading to a failing stroke volume response to exercise (Raeside et al., 2000). Stroke volume is determined by contractility and the enddiastolic volume (EDV). Holverda and co-workers showed that the failure to increase SV upon exercise in $\mathrm{PAH}$ patients was accompanied by a small increase in RV end diastolic volume (RVEDV) and a decrease in LV end diastolic volume (LVEDV) due to increased LVSB and RV forward failure hampering an adequate LV filling (Holverda et al., 2006). Using exercise studies during cardiac magnetic resonance imaging (cMRI) we found even a negative SV response, i.e. a decrease in SV upon exercise, in CTEPH patients; opposite from the response observed in healthy individuals. The observed maximal SV during exercise, thereby, correlated significantly with exercise capacity as expressed by peak oxygen consumption $\left(\mathrm{V}^{\prime} \mathrm{O}_{2}\right.$-peak), as well as with the hemodynamic severity of disease at rest.

Next to the decreased RV and LV function, responses related to ventilation-perfusion mismatching caused by the thromboembolic obstruction of the pulmonary vascular bed are also likely to play a significant role in the pathophysiology of the exercise limitation observed in CTEPH patients. (CTE)PH is associated with decreased ventilatory efficiency during exercise (D'Alonzo et al., 1987; Riley et al., 2000; Sun et al., 2001; Wasserman, 2004). As blood flow fails to perfuse the ventilated lung, dead space ventilation increases; to compensate for this increase in death space ventilation the patient's ventilatory requirement must increase. At the same time, the inability to increase cardiac output impairs oxygen transport appropriately in response to exercise, causing a low work rate "lactic acidosis" and exercise-induced hypoxemia, thereby further stimulating the ventilatory drive. Similar to measures of decreased cardiac output, parameters of increased dead space ventilation, were found to be related to the hemodynamic severity of disease in $\mathrm{PH}$ patients (Raeside et al., 2000; Van der Plas et al., 2010; Sun et al., 2001; Yasunobu et al., 2005).

The direct relation between exercise limitation and the hemodynamic severity of disease has lead to the use of (non-invasive) exercise testing for both prognostic and diagnostic information in (CTE)PH patients. The most commonly used test to study exercise tolerance in $\mathrm{PH}$ patients are the six minute walk test (6-MWT) and the symptom-limited cardiopulmonary exercise test (CPET).

\subsection{Exercise testing}

\subsubsection{Six minute walk test}

The 6-MWT is by far the most popular and most frequently used exercise test in PH clinical practice and research. The 6-MWT is derived from the Cooper test, a 12 minute running test that was developed to evaluate fitness in healthy individuals (Cooper, 1968). The 6-MWT itself is a reproducible, inexpensive, safe, and simple exercise test that requires no exercise equipment or advanced training for technicians. The 6-MWT can be used to evaluate exercise limitation in patients with cardiac and pulmonary diseases (ATS guidelines, 2002). Walking is a daily life activity that can be performed by all but the most severely impaired 
patients. The 6-MWT measures the distance walked on a flat, hard surface in a period of 6 minutes; the 6-minute walk distance (6-MWD). It evaluates the global and integrated responses of all systems involved during exercise, i.e. the pulmonary and cardiovascular system, systemic and peripheral circulation, neuromuscular units and muscle cell metabolism. In contrast to CPET, however, it does not provide specific information on the function of each of the different organs and systems involved in exercise or on the mechanism of the exercise limitation. As the 6-MWT is a self-paced walking test (patients choose their own intensity of exercise and are allowed to stop and rest during the test), it assesses a sub-maximal level of functional capacity. Nevertheless, the 6-MWD has been found to correlate closely with maximal oxygen uptake in various pulmonary and cardiac diseases (Cahalin et al., 1996; Roul et al., 1998). In iPAH patients, the six-minute walk distance (6-MWD) was shown to correlate significantly with hemodynamic severity of disease (Miyamoto et al., 2000). Similarly, we demonstrated in 50 consecutive patients with CTEPH prior to PEA, that the 6-MWD decreases in proportion to New York Heart Association (NYHA) functional class, and correlated strongly with the hemodynamic severity of disease (Figure 1). Compared to the data in iPAH patients, in CTEPH patients, the observed correlations between 6-MWD and pulmonary hemodynamics appeared even more robust (Reesink et al., 2007). Therefore, the 6-MWD is considered a highly useful objective parameter to assess functional limitations and outcome after medical interventions in most CTEPH patients.
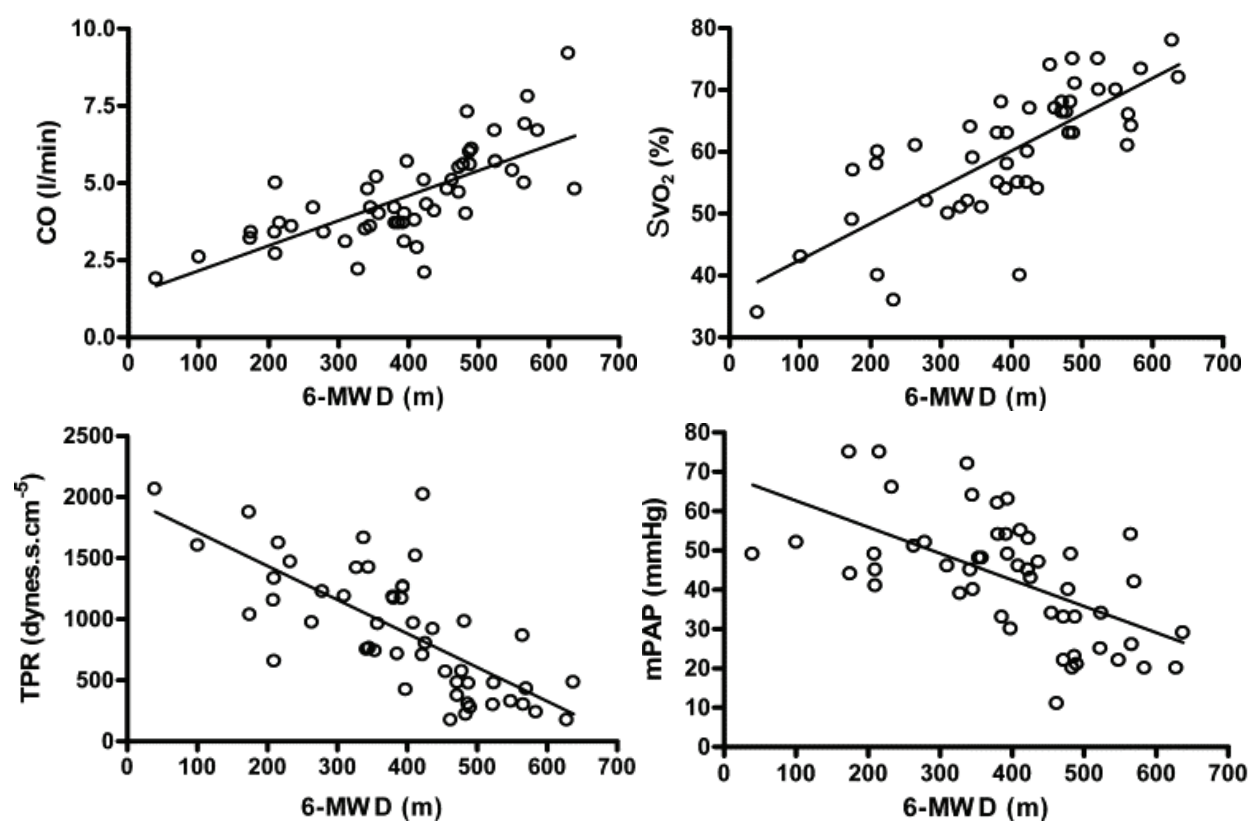

Fig. 1. Correlations between the 6-MWD and the pulmonary hemodynamic parameters. Top right: Mixed $\mathrm{SvO}_{2} ; \mathrm{n}=46$; Pearson $\mathrm{r}=0.77 ; P<0.0001$. Top left: $\mathrm{CO}$; Pearson $\mathrm{r}=0.76$; $P<0.0001$ Bottom left: TPR; Pearson $\mathrm{r}=-0.75 ; P<0.0001$ Bottom right: mPAP; Pearson $\mathrm{r}=-0.62 ; P<0.0001$. $m P A P$, mean pulmonary artery pressure; $6-M W D, 6$-minute walk distance; TPR, total pulmonary resistance; $\mathrm{CO}$, cardiac output; $\mathrm{SvO}_{2}$, venous oxygen saturation. (Adapted from: Reesink et al., 2007) 
The decrease in 6-MWD in patients with CTEPH is assumed to result from reduced maximum aerobic capacity owing to the, already discussed, inability of the heart to increase pulmonary blood flow adequately upon exercise. In the severely impaired CTEPH patients (NYHA stage III and IV), the 6-MWD was shown to reflect maximum aerobic capacity. However, we reported an increasing difference between maximal aerobic capacity and the aerobic capacity attained during 6-MWT, with decreasing severity of disease. In mildly impaired PH patients (NYHA stage II), the 6-MWT did not reflect maximal aerobic capacity. This indicates that mildly impaired $\mathrm{PH}$ patients are limited in their 6-MWT for other reasons than their oxygen delivery capacity. Therefore, in this group of patients, the 6-MWD may not be an appropriate parameter to study outcome of medical interventions (Van der Plas et al., 2008).

\subsubsection{Cardio pulmonary exercise testing}

CPET is considered the gold standard for the evaluation of exercise intolerance in patients with pulmonary and cardiac disease, and is based on the principle that system failure typically occurs while the system is under physical stress (Palange et al., 2007). CPET is based on a symptom-limited incremental exercise protocol in combination with breath-bybreath analysis of cardiopulmonary variables, such as oxygen consumption $\left(\mathrm{V}^{\prime} \mathrm{O}_{2}\right)$, carbon dioxide output $\left(\mathrm{V}^{\prime} \mathrm{CO}_{2}\right)$, minute ventilation $\left(\mathrm{V}_{\mathrm{E}}^{\prime}\right)$, heart rate $(\mathrm{HR})$ and arterial oxygen saturation. From these variables others can be calculated, like the oxygen pulse $\left(\mathrm{O}_{2}\right.$-pulse; $\mathrm{V}^{\prime} \mathrm{O}_{2} / \mathrm{HR}$ ) as derivative of stroke volume, and the ventilatory equivalent of $\mathrm{CO}_{2}$ $\left(\mathrm{V}_{\mathrm{E}}^{\prime} / \mathrm{V}^{\prime} \mathrm{CO}_{2}\right)$ as measure of ventilatory efficiency. As such, in contrast to the 6-MWT, CPET requires expensive equipment and well trained technicians. During CPET, workload is typically increased in a stepwise manner, depending on the predicted maximum exercise capacity of the patient; with the prerequisite that maximal effort should be attained in 10-15 minutes. All patients are stimulated to exercise to their personal maximum exercise capability, allowing peak exercise capacity to be determined. As opposed to the 6-MWT, CPET not only evaluates the global and integrated responses of all the organ systems involved during exercise, it also provides specific information on the function of each of the different components determining the exercise capacity. Maximal exercise capacity is determined by the "weakest link" in the interdependent physiological components of the gas transport mechanisms (Wasserman et al., 2004).

In PH, CPET has been shown to be a useful tool to assess the severity of disease and prognosis (Deboeck et al., 2004; Sun et al., 2001; Wensel et al., 2002; Yasunobu et al., 2005). CPET in patients with $\mathrm{PH}$ shows a distinct pattern of abnormal responses to exercise, with reductions in peak oxygen uptake $\left(\mathrm{V}^{\prime} \mathrm{O}_{2}\right.$-peak), $\mathrm{O}_{2}$ pulse, $\mathrm{V}^{\prime} \mathrm{O}_{2}$ at the anaerobic threshold and an increase in $\mathrm{V}_{\mathrm{E}}^{\prime} / \mathrm{V}^{\prime} \mathrm{CO}_{2}$. This pattern is well validated and has prognostic significance in patients with pulmonary arterial hypertension (D'Alonzo, et al. 1987; Sun, et al. 2001; Wasserman et al., 2004). In CTEPH, most of the patients we studied had by definition a reduced exercise capacity with a decreased peak oxygen uptake $\left(\mathrm{V}^{\prime} \mathrm{O}_{2}\right.$-peak), i.e. below $84 \%$ of the predicted value. On average, $\mathrm{V}^{\prime} \mathrm{O}_{2}$-peak and peak $\mathrm{O} 2$-pulse were decreased with increasing severity of $\mathrm{PH}$ (Figure 2). $\mathrm{V}^{\prime}{ }_{\mathrm{E}} / \mathrm{V}^{\prime} \mathrm{CO}_{2}$ at anaerobic threshold was increased in almost all patients. $\mathrm{V}^{\prime} \mathrm{O}_{2}$-peak showed a significant inverse correlation with resting mean pulmonary arterial pressure and total pulmonary resistance $(\mathrm{r}=-0.625, \mathrm{p}=0.007$ and $\mathrm{r}=-0.676$, $\mathrm{p}=0.003$ respectively). 

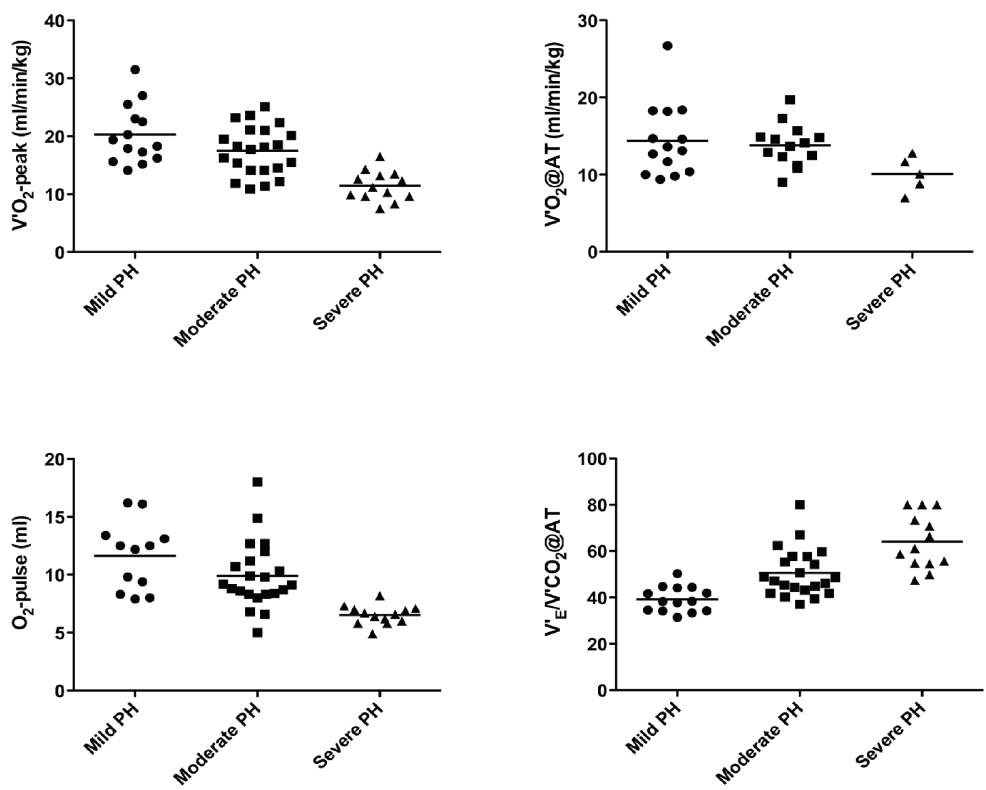

Fig. 2. Characteristic abnormalities of exercise parameters in CTEPH patients $(n=49)$ with mild PH (mPAP $<30 \mathrm{mmHg})$, moderate PH (mPAP $\geq 30, \leq 50 \mathrm{mmHg}$ ) or severe $\mathrm{PH}(>50 \mathrm{mmHg}) . V^{\prime} \mathrm{O}_{2}$-peak = peak oxygen uptake. $V^{\prime} \mathrm{O}_{2} @ \mathrm{AT}=$ oxygen uptake at anaerobic threshold; $\mathrm{O}_{2}$-pulse = oxygen pulse; $\mathrm{V}_{\mathrm{E}}^{\prime} / \mathrm{V}^{\prime} \mathrm{CO}_{2}=$ ventilation equivalent for carbon dioxide (unpublished data).

\section{Pathophysiology of dyspnea in CTEPH}

The one common presenting symptom in patients with CTEPH is dyspnea (Jamieson et al., 2000; Viner et al., 1994). Dyspnea is associated with decreased exercise performance, functional status and quality of life (Wasserman, 2004). Dyspnea includes several qualitatively distinct sensations that can arise from different pathophysiological mechanisms. In general, it is considered to be the result of a complex interaction of signals originating within the central nervous system and a variety of signals from receptors in the upper airway, lungs and chest wall (Manning et al., 1995; Yasunobo et al., 1999).

Dyspnea can be assessed by the NYHA functional classification and the Borg score. NYHA functional class is a doctor reported dyspnea scoring system that quantifies a patient's level of exercise intolerance, expressing the patients (dis)ability to perform everyday activities. The Borg score, on the other hand, is a patient reported quantitative scaling method of the symptomatic dyspnea. Patients rate their own dyspnea on a scale from 0 (no dyspnea) to 10 (absolutely breathlessness) (Borg, 1982).

In CTEPH, dyspnea can be attributed to multiple factors: increased dead space ventilation, hypoxemia, sympathetic overstimulation and/or stimulation of pressure receptors in the pulmonary vascular bed may all give rise to an increased ventilatory demand (Manning et al., 1995). This will contribute to an increase in respiratory motor output with a corresponding increase in the sense of effort, i.e. the work of breathing. Increased dead space ventilation, caused by ventilation-perfusion mismatching due to thromboembolic obstruction in the 
vascular bed might be an attributable factor to the sensation of dyspnea in CTEPH patients (Sun et al., 2001). Dead space ventilation increases, as blood flow fails to perfuse the ventilated lung. To compensate for this increase in dead space ventilation the patient's ventilatory requirement increases, leading to a sensation of dyspnea. Recently, we reported on this relation between dead space ventilation and the experienced dyspnea in fifty-four patients with CTEPH who underwent PEA (Van der Plas, et al. 2010). The dead space ventilation $\left(\mathrm{V}_{\mathrm{D}} / \mathrm{V}_{\mathrm{T}}\right)$, as determined by the Bohr-Enghoff equation, was shown to be increased, and correlated significantly with the hemodynamic severity of disease as well as with patientreported sensations of dyspnea as assessed by the Borg score and NYHA functional class. Assessment of the expiratory end tidal $\mathrm{PCO}_{2}\left(\mathrm{PET}, \mathrm{CO}_{2}\right)$ by capnography showed a significant lower $\mathrm{PET}, \mathrm{CO}_{2}$ compared to the arterial $\mathrm{PCO}_{2}\left(\mathrm{~Pa}_{2} \mathrm{CO}_{2}\right)(3.55 \pm 0.43$ vs. $4.46 \pm 0.42 \mathrm{kPa}$, $\mathrm{p}<0.001$ ), indicating a parallel origin of the observed dead space ventilation (Figure 3 ).
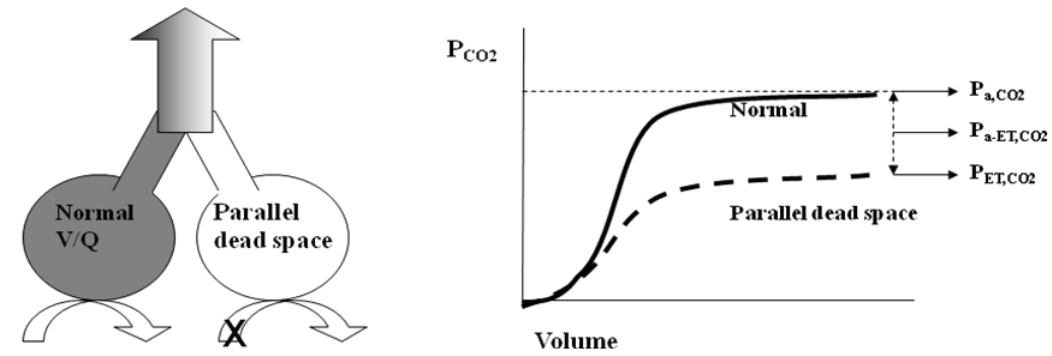

Fig. 3. Model of parallel dead space ventilation. (Adapted from: Van der Plas et al., 2010)

Even more, ventilation itself is stretched beyond the demands of the increased dead space, since patients were relatively hypocapnic, i.e. a $\mathrm{Pa}_{1} \mathrm{CO}_{2}$ below the clinical limit of $4.7 \mathrm{kPa}$. Moreover, $\mathrm{Pa}, \mathrm{CO}_{2}$ correlated inversely with $\mathrm{mPAP}$ and TPR. The combination of alveolar hyperventilation and increased (parallel) dead space ventilation is remarkable as it puts an extra ventilatory drive on an already increased effort of breathing. These findings are in unison with reports in patients with iPAH (Meyer et al., 2005; Wessel et al., 1964; Zoia et al., 2002). The alveolar hyperventilation seemed to be only in part hypoxic driven, as administration of $100 \%$ oxygen for at least 20 minutes increased but did not normalize $\mathrm{Pa}, \mathrm{CO}_{2}(4.50 \pm 0.42 \mathrm{kPa}$ vs. 4.58 $\pm 0.42 \mathrm{kPa}$ ). Increased sympathetic activity may play a causative role in the observed alveolar hyperventilation in our patients. Velez-Roa and colleagues found muscle sympathetic nerve activity (MSNA) to be elevated in patients with idiopathic and fenfluramine induced PAH (Velez-Roa et al., 2004). As with $\mathrm{Pa}, \mathrm{CO}_{2}$ in our study, MSNA changed towards normal, but did not normalize by administration of hyperoxia. Increased sympathetic activation has been reported to increase ventilation (Jordan et al., 2000). The presence and cause of increased MSNA in patients with CTEPH and the relation between increased MSNA and alveolar hyperventilation might be subject of further research.

\section{Effects of surgical treatment by pulmonary endarterectomy}

\subsection{Restoration of cardiac function}

Pulmonary endarterectomy, first reported in 1958 by Hurwitt and co-workers (Hurwitt et al., 1958), remains the therapy of choice for patients with CTEPH and surgical accessible thrombi (Fedullo et al., 2011). PEA causes an instantaneous and permanent hemodynamic improvement (Corsico et al., 2008; D'Armini et al., 2007; Reesink et al., 2007), which is associated with an improvement in overall cardiac function already shortly after PEA. 
The most widely used non-invasive tool in clinical practice to study RV dysfunction is echocardiography. In CTEPH, echocardiographically, restoration of overall RV function shortly after PEA was reported (Menzel et al., 2000; Menzel et al., 2002; Menzel et al., 2002). In fact, improvement of RV geometry and LV diastolic function after PEA was already reported by Dittrich and co-workers in 1988 and 1989 (Dittrich et al., 1988; Dittrich et al., 1989). In addition, reverse RV remodeling, that is improvement of RV dimensions and ejection fraction, was demonstrated in patients with iPAH after lung transplantation (Kasimir et al., 2004; Vizza et al., 1998). The usefulness of echocardiography in this respect, however, is somewhat limited due to its technical limitations (acoustic window) and the absence of a reliable mathematical assumption due to the complex geometry of the RV. In view of these limitations, cardiac MRI is considered a superior imaging technique to quantify the characteristics of RV function and morphology (Helbing et al., 1995; Mayer et al., 1996; Vogel et al., 1997). Using cMRI we and others have shown restoration of RV remodeling after hemodynamically successful PEA (Kreitner et al., 2007, 2004; Reesink et al., 2007). We studied the restoration of RV remodeling in CTEPH patients at least 4 months after PEA (Reesink et al., 2007). After PEA, RV end diastolic and systolic dimensions normalized; RV-SVI and RV-EF improved, but did not fully normalize compared to healthy controls. Also, RV hypertrophy (RV mass) decreased after PEA, but did not fully normalize in all patients. In addition, LVSB, preoperatively present in 15 of the 17 patients studied, normalised after PEA. Moreover, the observed decrease in RV mass and change in LVSB correlated significantly with the observed postoperative hemodynamic improvement. Finally, after PEA, LV end-diastolic volume and the LV-EF, both decreased prior to PEA, normalized (Figure 4 and 5). Recently, Lino and co-workers studied the time course of the restoration of the RV remodeling and showed that it occurs early after PEA. In line with our observations, the parameters of RV remodeling did not fully normalize after a 6months follow-up period (Iino et al., 2008).
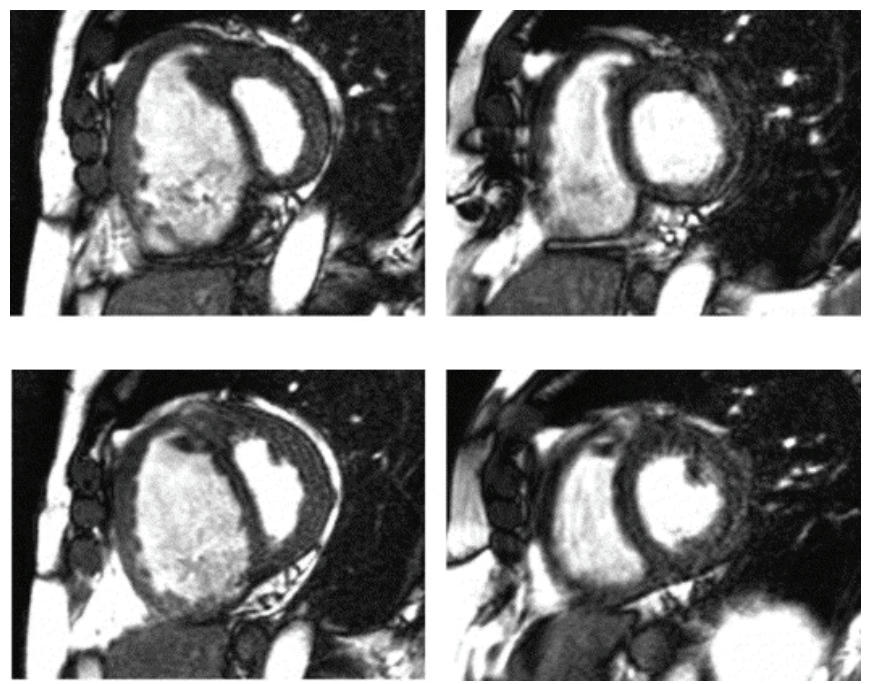

Fig. 4. MRI short-axis cine images at basal (upper panel) and mid-ventricular (lower panel) level, before (A) and after (B) PEA (relative time 55\% in the cardiac cycle). Note the encroachment of the interventricular septum into the LV before PEA and the restoration of the septal bowing to normal after PEA. Note also the reversal of RV hypertrophy and the normalization of the RV and LV volumes (Adapted from: Reesink et al., 2007) 

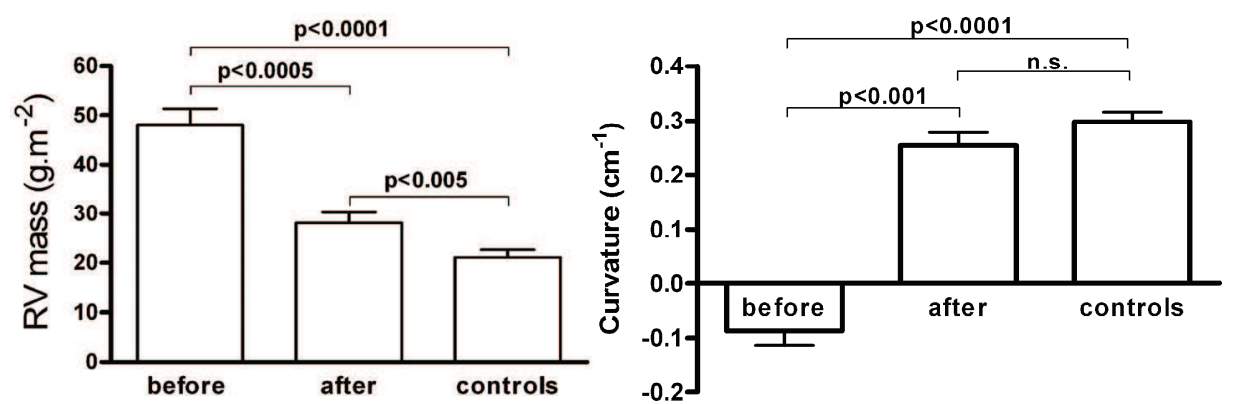

Fig. 5. Left: Right ventricle mass in patients with CTEPH $(n=17)$ before and after PEA compared with healthy controls $(n=12)$. Data are expressed as mean \pm SEM. Right: Septal bowing (curvature: $1 / \mathrm{R})$ in patients with CTEPH $(n=17)$ before and after PEA compared with healthy controls $(n=12)$. Data are expressed as mean \pm SE (Adapted from Reesink et al., 2007)

As already extensively discussed, RV dysfunction and LV dysfunction occur in CTEPH patients because both are closely interdependent (Hardziyenka et al., 2011). Decreased RV ejection fraction relates to decreased LV diastolic filling and this may induce LV atrophy. As mentioned, we have observed a significant lower LV free wall mass index as determined by cMRI in CTPEH patients with RV dysfunction. In these patients, after PEA restoration of the LV free wall mass to normal values was observed (Hardziyenka et al., 2011) Recently, we also have reported on our studies on the time course of the restoration of RV systolic and diastolic function after PEA by use of echocardiography (Surie et al., 2011). Two weeks after PEA RV afterload and dimensions had decreased significantly, without further improvement during follow-up. Global RV function, expressed by the myocardial performance index (MPI) (Tei et al., 1996), showed a gradual improvement during the follow-up period. In contrast, 2 weeks after PEA systolic RV function, as assessed by tricuspid annular plane systolic velocity excursion (TAPSE) (Forfia et al., 2006) (Figure 6) and peak tricuspid annular systolic velocity of the RV (Saxena et al., 2006), had worsened, with a subsequent incomplete restoration during follow-up. Also, the diastolic RV function, as determined by the tricuspid-to-annulus ratio (TDI E/E') (Lim et al., 2009) (Figure 6)
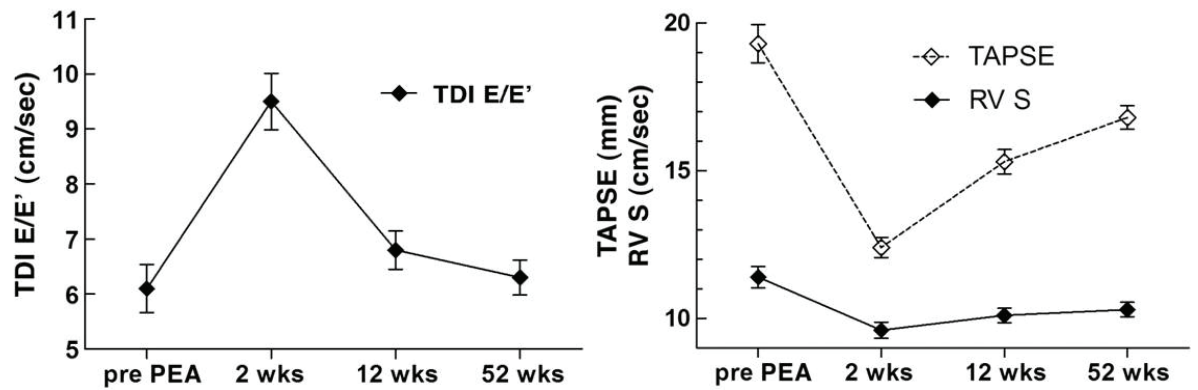

Fig. 6. Time course of restoration of diastolic (TDI E/E'; left) and systolic (TAPSE; right) RV function after PEA (Adapted from: Surie et al., 2011).

showed a similar biphasic response. The observed perioperative dynamics of systolic and diastolic RV function after PEA are in line with studies in patients undergoing coronary artery bypass graft (CABG) surgery for coronary artery disease. The mechanism of the 
isolated effect on systolic and diastolic RV function remains fully unclear; however, it does not appear solely related to the use of cardiopulmonary bypass (Unsworth et al., 2010). Ischemia, inflammation, and myocardial oedema have been suggested; it can be hypothesized that the hypertrophied and dilated RV in patients with CTEPH might be even more sensitive to ischaemia or other surgery-related injury.

\subsection{Restoration of exercise tolerance}

\subsubsection{Restoration of stroke volume response}

Exercise tolerance in patients with CTEPH is limited by an inadequate RV stroke volume response upon exercise. As previously discussed, preoperatively, SV decreases during exercise in patients with CTEPH; moreover, SV during exercise is related to exercise capacity as expressed by $\mathrm{V}^{\prime} \mathrm{O}_{2}$-peak as well as the hemodynamic severity of disease. One year after PEA, we demonstrated restoration of the SV response: change upon exercise in SVI pre-PEA: $-2.8 \pm 4.6 \mathrm{ml} / \mathrm{m}^{2}$ vs. change upon exercise SVI post-PEA: $4.0 \pm 4.9 \mathrm{ml} . \mathrm{m}^{2}$ $(p<0.001$; Table 1). The restoration of the SV response was accompanied by an increase in exercise tolerance, and by restoration of cardiac remodelling as assessed by cMRI. However, postoperatively, in some preoperatively more severely affected patients we still observed a negative SV response during exercise, despite (near) normalization in pulmonary hemodynamics.

\begin{tabular}{|c|c|c|c|c|c|c|}
\hline & \multicolumn{2}{|l|}{ Controls } & \multicolumn{2}{|l|}{ Pre PEA } & \multicolumn{2}{|l|}{ Post PEA } \\
\hline & Rest & Exercise & Rest & Exercise & Rest & Exercise \\
\hline SVI, $m l \cdot m^{-2}$ & $46.6 \pm 7.6$ & $57.9 \pm 11.8$ & $35.9 \pm 7.4^{\#}$ & $33.0 \pm 9.0$ *\# & $35.9 \pm 5.2^{\#}$ & $39.9 \pm 5.4$ * \# \# \\
\hline HR, min $^{-1}$ & $65 \pm 10$ & $94 \pm 8$ & $69 \pm 12$ & $93 \pm 13^{*}$ & $73 \pm 11$ & $97 \pm 9.0$ * \\
\hline $\mathbf{C I}, l . \mathrm{min}^{-1} \cdot \mathrm{m}^{-2}$ & $3.0 \pm 0.3$ & $5.4 \pm 1.1$ & $2.4 \pm 0.4$ \# & $3.0 \pm 0.8^{\text {*\# }}$ & $2.6 \pm 0.5$ & $3.8 \pm 0.5$ *\#\# \\
\hline
\end{tabular}

Table 1. Stroke volume index (SVI), heart rate (HR) and cardiac index (CI) values at rest and during sub-maximal exercise for healthy controls and CTEPH patients before and after PEA. Data are expressed as mean \pm SD. ${ }^{*} p<0.05$ compared to resting conditions, $\ddagger \mathrm{p}<0.05$ post PEA compared to pre PEA, \# p<0.05 compared with healthy controls (Van Kan et al., unpublished data).

\subsubsection{Six-minute walk test}

We systematically studied the effects of PEA on the restoration of exercise tolerance by the 6-MWT, and assessed its relation with the hemodynamic improvement observed shortly after surgery. One year after PEA, the 6-MWD had increased significantly, and the change correlated with the observed hemodynamic improvement. Moreover, in patients with normalized pulmonary hemodynamics after PEA, the 6-MWD, expressed as percentage of the predicted value, even tended to normalize (Reesink et al., 2007).

In addition, we studied the time course of the postoperative functional recovery of patients with CTEPH up to 5 years after PEA. Whereas NYHA functional class and sPAP improved within the first 3 months after PEA without further improvement, the 6-MWD showed a gradual improvement over a 2-year follow-up period. Interestingly, the dynamics of functional recovery parallel the observed time course of the restoration of RV systolic and diastolic function. Furthermore, patients with residual pulmonary hypertension after PEA showed a greater improvement in 6-MWD, despite their worse absolute outcome (Van der Plas et al., 2011). 
The improvement observed in 6-MWD after PEA can be explained in major part by an increase in maximum aerobic capacity due to the restoration of the SV response upon exercise due to instantaneous decrease in right ventricle afterload. This is supported by our observations that the increase in 6-MWD upon PEA was not associated with a concomitant increase in heart rate; this implicates that PEA improves cardiac output by improving RV SV response and thereby decreasing the need for a chronotropic response. (Van der Plas et al., 2010). A second contributing factor appears decrease in dead space ventilation due to the restoration of pulmonary blood flow. The decrease in dead space ventilation was shown to be associated with an improvement of dyspnea symptoms upon exercise as ventilatory demand decreases (Van der Plas et al., 2010). Another factor, which has been suggested to attribute to the observed long-term improvement of 6-MWD after PEA, might be a longterm restoration of secondary arteriopathy which accommodates greater blood flow and improves gas exchange (Thistlethwaite et al, 2011).

\subsubsection{Cardiopulmonary exercise testing}

In addition to the restoration of SV response during exercise assessed by cMRI, we also studied the restoration of exercise tolerance in CTEPH patients after PEA by use of CPET. Pre-operatively maximal SV, assessed by cMRI, during exercise correlated with $\mathrm{V}^{\prime} \mathrm{O}_{2}$-peak $(\mathrm{r}=0.688, \mathrm{p}=0.002)$ and $\mathrm{O}_{2}$-pulse $(\mathrm{r}=0.759, \mathrm{p}<0.001)$, and exercise SV correlated inversely with mPAP ( $\mathrm{r}=-0.719, \mathrm{p}=0.001)$ and TPR $(\mathrm{r}=-0.656, \mathrm{p}=0.001)$.

After PEA, we observed a normalization in exercise capacity in 11 out of 13 patients studied. $\mathrm{V}^{\prime} \mathrm{O}_{2}$-peak, peak workload and peak $\mathrm{O}_{2}$-pulse increased significantly while peak $\mathrm{HR}$ and peak $\mathrm{V}_{\mathrm{E}}^{\prime}$ remained unchanged. $\mathrm{V}_{\mathrm{E}}^{\prime} / \mathrm{V}^{\prime} \mathrm{CO}_{2}$ showed a significant decrease, but normalized in 8 out of 13 patients only (Table 2). Changes in $\mathrm{V}^{\prime} \mathrm{O}_{2}$-peak from baseline to 1 year post PEA, correlated significant with the directly after PEA observed changes in mPAP.

\begin{tabular}{|l|l|l|}
\hline Exercise parameters & Pre PEA & Post PEA \\
\hline$V^{\prime} \mathrm{O}_{2}-$ peak, (\% predicted) & $72.5 \pm 13.0$ & $99 \pm 13^{*}$ \\
\hline Peak workload, $(\%$ predicted $)$ & $71 \pm 23$ & $97 \pm 30^{*}$ \\
\hline $\mathrm{O}_{2}-$ pulse, $(\%$ predicted) & $75 \pm 13$ & $95 \pm 14^{*}$ \\
\hline$V_{E}^{\prime} / V^{\prime} \mathrm{CO}_{2}$ & $49.8 \pm 11.2$ & $32.7 \pm 4.0^{*}$ \\
\hline Peak $\mathrm{HR},(\%$ predicted) & $91 \pm 8$ & $94 \pm 10$ \\
\hline Peak $V_{E}^{\prime},(\%$ predicted $)$ & $98 \pm 19$ & $92 \pm 14$ \\
\hline
\end{tabular}

Table 2. Data are expressed as mean \pm SD. $V^{\prime} \mathrm{O}_{2}=$ oxygen uptake; $\mathrm{O}_{2}$-pulse = oxygen pulse; $\mathrm{V}_{\mathrm{E}}^{\prime}=$ minute ventilation; $\mathrm{V}_{\mathrm{E}}^{\prime} / \mathrm{V}^{\prime} \mathrm{CO}_{2}=$ ventilation equivalent for carbon dioxide; $\mathrm{HR}=$ heart rate. ${ }^{*} \mathrm{p}<0.05$ post PEA compared to pre PEA (Van Kan et al., unpublished data).

\subsection{Effects of pulmonary endarterectomy on dyspnea}

Dyspnea can be assessed by using NYHA functional classification and the patient reported Borg score. In a cohort of fifty-four consecutive CTEPH patients both NYHA functional class (Figure 9) and resting Borg scores (Figure 8) improved after PEA. The change after PEA in NYHA functional class and resting Borg scores were independently correlated with the changes observed in absolute dead space and dead space ventilation, as well as with the hemodynamic improvement.

As we have shown, the increase in dead space ventilation in CTEPH patients is significantly correlated with the hemodynamic severity of disease. After PEA, dead space ventilation 
decreases, and was shown to normalize in the majority of patients. Hence, although the primary objective of PEA is to lower the right ventricular afterload, normalization of dead space by surgical removal of chronic thromboembolism contributed significantly to the postoperative recovery of the symptomatic dyspnea.
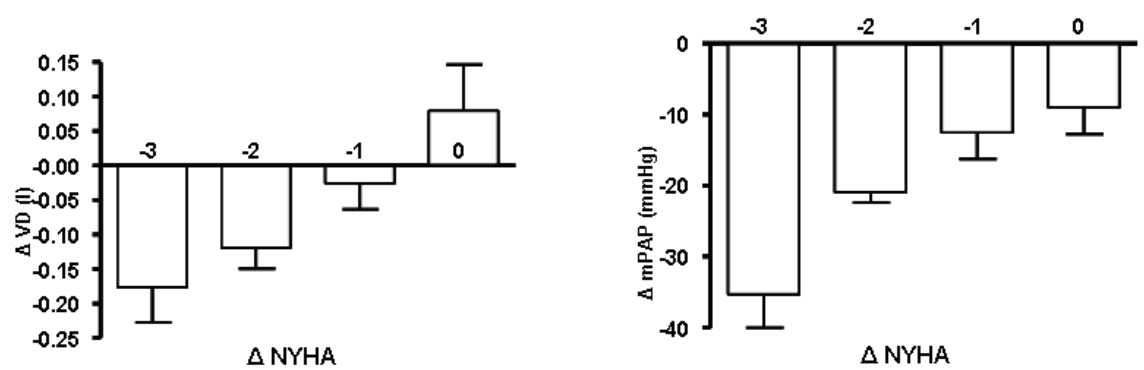

Fig. 8. Change in absolute dead space (Delta $V_{D}$ ) and change in mean pulmonary arterial pressure (Delta mPAP) against changes in NYHA functional class (Delta NYHA) (Adapted from: Van der Plas et al., 2010).
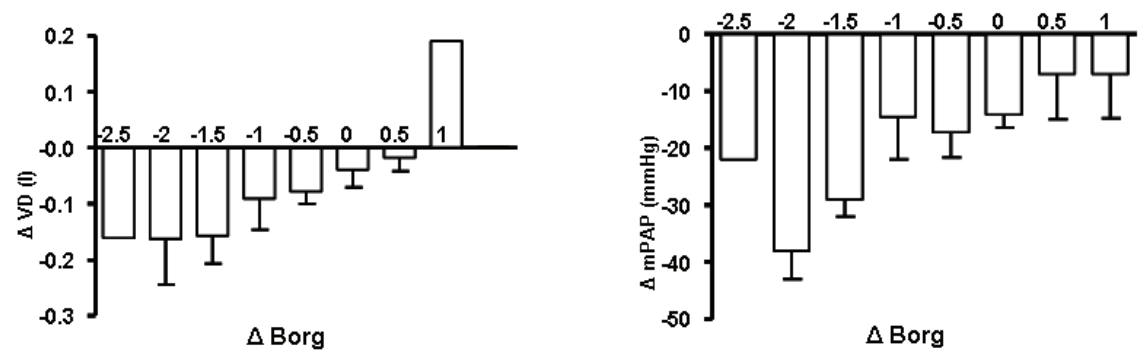

Fig. 9. Change in absolute dead space (Delta $V_{D}$ ) and change in mean pulmonary arterial pressure (Delta mPAP) against changes in Borg score at rest (Delta Borg) (Adapted from: Van der Plas et al., 2010).

\section{Future research}

In this overview, at least one possibly important factor contributing to the exercise limitation observed in CTEPH patients has not been addressed. The main focus of our studies has been on the cardiac and ventilatory contributing components. However, recently a reduction in respiratory and peripheral muscle strength has been observed in patients with $\mathrm{PAH}$ which may be a determinant of exercise performance as well (Bauer et al., 2007; de Man et al., 2009; Mainguy et al., 2010; Meyer et al., 2005). The underlying mechanisms responsible for muscle weakness in PH patients are not yet known. In COPD and chronic (left) heart failure multiple mechanisms have been suggested to be involved in reduced muscle strength; changes in muscle fibre type ratio, abnormal intracellular $\mathrm{Ca}^{2+}$ profile, impaired muscle perfusion, decreased number of mitochondria, decreased oxidative enzymes, electrolyte disturbance, steroid therapy, malnutrition, wasting and cardiac cachexia. Most of these mechanisms do not seem to apply in PH (Meyer et al., 2005). However, we observed an increase in body mass index (BMI) one year after PEA in patients with CTEPH; in 48 
consecutive CTEPH patients the BMI increased from $29.7 \pm 5.6$ preoperatively to $30.8 \pm 5.7$ at 1 year after surgery $(p=0.001)$. Based upon this observation, it might be hypothesized that some form of preoperative malnutrition or wasting may occur in CTEPH patients despite their in itself normal BMI. In COPD and heart failure, weight loss and loss of fat-free mass were shown to be associated with systemic inflammation (Anker et al., 2002; Decramer et al., 2001; Gosker et al., 2000; Anker et al., 2002; Decramer et al., 2001; Gosker et al., 2000). Langer and colleagues found that heart failure due to CTEPH also appears to generate a pronounced systemic inflammatory response with the release of pro-inflammatory and antiinflammatory cytokines; moreover, PEA resulted in the normalization of preoperatively elevated TNF-alpha levels (Langer et al., 2004). Future research should focus on the clarification of the possible relationship between exercise intolerance, muscle weakness and systemic inflammation induced wasting in (CTE) $\mathrm{PH}$ patients. CTEPH patients can serve as an excellent model for these studies, in which the effect of PEA on muscle strength, body composition and systemic inflammation, and the relationships in its changes can be studied.

\section{Conclusions}

CTEPH results from incomplete resolution of the vascular obstruction caused by pulmonary thromboembolism. Patients typically present themselves with gradually exercise intolerance, portrayed as exertional dyspnea. Exercise is primarily limited by the inability of the right ventricle to sufficiently increase pulmonary blood flow upon exercise. If left untreated, the increased resistance and pulmonary arterial pressure leads to progressive cardiac remodeling with consequent impact on cardiac function. In addition, in CTEPH dead space ventilation is increased due to the vascular obstruction; and dead space ventilation correlates to the patient's experienced dyspnea.

Pulmonary endarterectomy is the therapy of choice for patients with CTEPH and surgical accessible thrombi. PEA causes an instantaneous and permanent hemodynamic improvement, which is (over time) associated with a restoration of parameters of RV and LV remodeling and function. Exercise tolerance increases primarily due to the improvement in stroke volume response. However, full symptomatic recovery also seems to depend on normalisation of dead space ventilation due to the restoration of pulmonary blood flow as a result of the surgical removal of chronic thromboembolism.

\section{References}

(2002). ATS statement: guidelines for the six-minute walk test. Am J Respir.Crit Care Med, Vol.166, No.1, pp. 111-117, ISSN 1073-449X

Alpert, J.S.(2001). The effect of right ventricular dysfunction on left ventricular form and function. Chest, Vol.119, No.6, pp. 1632-1633,

Anker, S.D. \& Sharma, R.(2002). The syndrome of cardiac cachexia. Int.J.Cardiol., Vol.85, No.1, pp. 51-66,

Archibald, C.J., Auger, W.R., \& Fedullo, P.F.(1999). Outcome after pulmonary thromboendarterectomy. Semin.Thorac.Cardiovasc.Surg, Vol.11, No.2, pp. 164-171, ISSN 1043-0679

Auger, W.R., Permpikul, P., \& Moser, K.M.(1995). Lupus anticoagulant, heparin use, and thrombocytopenia in patients with chronic thromboembolic pulmonary 
hypertension: a preliminary report. Am J Med, Vol.99, No.4, pp. 392-396, ISSN 00029343

Auger, W.R., Kim, N.H., Kerr, K.M., Test, V.J., \& Fedullo, P.F.(2007). Chronic thromboembolic pulmonary hypertension. Clin Chest Med, Vol.28, No.1, pp. 255-69, $x$, ISSN 0272-5231

Bauer, M., Wilkens, H., Langer, F., Schneider, S.O., Lausberg, H., \& Schafers, H.J.(2002). Selective upregulation of endothelin $\mathrm{B}$ receptor gene expression in severe pulmonary hypertension. Circulation, Vol.105, No.9, pp. 1034-1036, ISSN 1524-4539

Bauer, R., Dehnert, C., Schoene, P., Filusch, A., Bartsch, P., Borst, M.M., Katus, H.A., \& Meyer, F.J.(2007). Skeletal muscle dysfunction in patients with idiopathic pulmonary arterial hypertension. Respir.Med, Vol.101, No.11, pp. 2366-2369, ISSN 0954-6111

Becattini, C., Agnelli, G., Pesavento, R., Silingardi, M., Poggio, R., Taliani, M.R., \& Ageno, W.(2006). Incidence of chronic thromboembolic pulmonary hypertension after a first episode of pulmonary embolism. Chest, Vol.130, No.1, pp. 172-175, ISSN 00123692

Bonderman, D., Martischnig, A.M., Vonbank, K., Nikfardjam, M., Meyer, B., Heinz, G., Klepetko, W., Naeije, R., \& Lang, I.M.(2011). Right ventricular load at exercise is a cause of persistent exercise limitation in patients with normal resting pulmonary vascular resistance after pulmonary endarterectomy. Chest, Vol.139, No.1, pp. 122127 ,

Bonderman, D., Wilkens, H., Wakounig, S., Schafers, H.J., Jansa, P., Lindner, J., Simkova, I., Martischnig, A.M., Dudczak, J., Sadushi, R., Skoro-Sajer, N., Klepetko, W., \& Lang, I.M.(2009). Risk factors for chronic thromboembolic pulmonary hypertension. Eur Respir.J, Vol.33, No.2, pp. 325-331, ISSN 1399-3003

Bonderman, D., Jakowitsch, J., Adlbrecht, C., Schemper, M., Kyrle, P.A., Schonauer, V., Exner, M., Klepetko, W., Kneussl, M.P., Maurer, G., \& Lang, I.(2005). Medical conditions increasing the risk of chronic thromboembolic pulmonary hypertension. Thromb.Haemost., Vol.93, No.3, pp. 512-516, ISSN 0340-6245

Bonderman, D., Turecek, P.L., Jakowitsch, J., Weltermann, A., Adlbrecht, C., Schneider, B., Kneussl, M., Rubin, L.J., Kyrle, P.A., Klepetko, W., Maurer, G., \& Lang, I.M.(2003). High prevalence of elevated clotting factor VIII in chronic thromboembolic pulmonary hypertension. Thromb.Haemost., Vol.90, No.3, pp. 372-376, ISSN 03406245

Borg, G.A.(1982). Psychophysical bases of perceived exertion. Med Sci Sports Exerc., Vol.14, No.5, pp. 377-381, ISSN 0195-9131

Cahalin, L.P., Mathier, M.A., Semigran, M.J., Dec, G.W., \& DiSalvo, T.G.(1996). The sixminute walk test predicts peak oxygen uptake and survival in patients with advanced heart failure. Chest, Vol.110, No.2, pp. 325-332, ISSN 0012-3692

Colorio, C.C., Martinuzzo, M.E., Forastiero, R.R., Pombo, G., Adamczuk, Y., \& Carreras, L.O.(2001). Thrombophilic factors in chronic thromboembolic pulmonary hypertension. Blood Coagul.Fibrinolysis, Vol.12, No.6, pp. 427-432, ISSN 0957-5235

Condliffe, R., Kiely, D.G., Gibbs, J.S., Corris, P.A., Peacock, A.J., Jenkins, D.P., Hodgkins, D., Goldsmith, K., Hughes, R.J., Sheares, K., Tsui, S.S.L., Armstrong, I.J., Torpy, C., Crackett, R., Carlin, C.M., Das, C., Coghlan, J.G., \& Pepke-Zaba, J.(2008). Improved outcomes in medically and surgically treated chronic thromboembolic pulmonary 
hypertension. Am J Respir.Crit Care Med, Vol.177, No.10, pp. 1122-1127, ISSN 15354970

Cooper, K.H.(1968). A means of assessing maximal oxygen intake. Correlation between field and treadmill testing. JAMA, Vol.203, No.3, pp. 201-204, ISSN 0098-7484

Corsico, A.G., D'Armini, A.M., Cerveri, I., Klersy, C., Ansaldo, E., Niniano, R., Gatto, E., Monterosso, C., Morsolini, M., Nicolardi, S., Tramontin, C., Pozzi, E., \& Vigano, M.(2008). Long-term outcome after pulmonary endarterectomy. Am J Respir.Crit Care Med, Vol.178, No.4, pp. 419-424, ISSN 1535-4970

Cournand, D.A. \& Riley, R.L.(1950). Pulmonary circulation and alveolar ventilation perfusion relationships after pneumonectomy. J Thorac.Surg, Vol.19, No.1, pp. 80116, ISSN 0096-5588

D'Alonzo, G.E., Gianotti, L.A., Pohil, R.L., Reagle, R.R., DuRee, S.L., Fuentes, F., \& Dantzker, D.R.(1987). Comparison of progressive exercise performance of normal subjects and patients with primary pulmonary hypertension. Chest, Vol.92, No.1, pp. 57-62, ISSN 0012-3692

D'Armini, A.M., Zanotti, G., Ghio, S., Magrini, G., Pozzi, M., Scelsi, L., Meloni, G., Klersy, C., \& Vigano, M.(2007). Reverse right ventricular remodeling after pulmonary endarterectomy. J.Thorac.Cardiovasc.Surg., Vol.133, No.1, pp. 162-168,

de Man, F.S., Handoko, M.L., Groepenhoff, H., 't Hul, A.J., Abbink, J., Koppers, R.J.H., Grotjohan, H.P., Twisk, J.W.R., Bogaard, H.J., Boonstra, A., Postmus, P.E., Westerhof, N., van der Laarse, W.J., \& Vonk-Noordegraaf, A.(2009). Effects of exercise training in patients with idiopathic pulmonary arterial hypertension. Eur Respir.J, Vol.34, No.3, pp. 669-675, ISSN 1399-3003

Deboeck, G., Niset, G., Lamotte, M., Vachiery, J.L., \& Naeije, R.(2004). Exercise testing in pulmonary arterial hypertension and in chronic heart failure. Eur Respir.J, Vol.23, No.5, pp. 747-751, ISSN 0903-1936

Decramer, M.(2001). Respiratory muscles in COPD: regulation of trophical status. Verh.K.Acad.Geneeskd.Belg., Vol.63, No.6, pp. 577-602,

Dittrich, H.C., Chow, L.C., \& Nicod, P.H.(1989). Early improvement in left ventricular diastolic function after relief of chronic right ventricular pressure overload. Circulation, Vol.80, No.4, pp. 823-830,

Dittrich, H.C., Nicod, P.H., Chow, L.C., Chappuis, F.P., Moser, K.M., \& Peterson, K.L.(1988). Early changes of right heart geometry after pulmonary thromboendarterectomy. J.Am.Coll.Cardiol., Vol.11, No.5, pp. 937-943,

Fedullo, P.F., Auger, W.R., Kerr, K.M., \& Rubin, L.J.(2001). Chronic thromboembolic pulmonary hypertension. N.Engl.J Med, Vol.345, No.20, pp. 1465-1472, ISSN 00284793

Fedullo, P., Kerr, K.M., Kim, N.H., \& Auger, W.R.(2011). Chronic thromboembolic pulmonary hypertension. Am J Respir.Crit Care Med, Vol.183, No.12, pp. 1605-1613, ISSN 1535-4970

Fleg, J.L., Pina, I.L., Balady, G.J., Chaitman, B.R., Fletcher, B., Lavie, C., Limacher, M.C., Stein, R.A., Williams, M., \& Bazzarre, T.(2000). Assessment of functional capacity in clinical and research applications: An advisory from the Committee on Exercise, Rehabilitation, and Prevention, Council on Clinical Cardiology, American Heart Association. Circulation, Vol.102, No.13, pp. 1591-1597, ISSN 1524-4539 
Forfia, P.R., Fisher, M.R., Mathai, S.C., Housten-Harris, T., Hemnes, A.R., Borlaug, B.A., Chamera, E., Corretti, M.C., Champion, H.C., Abraham, T.P., Girgis, R.E., \& Hassoun, P.M.(2006). Tricuspid annular displacement predicts survival in pulmonary hypertension. Am.J.Respir.Crit Care Med., Vol.174, No.9, pp. 1034-1041,

Galie, N., Hoeper, M.M., Humbert, M., Torbicki, A., Vachiery, J.L., Barbera, J.A., Beghetti, M., Corris, P., Gaine, S., Gibbs, J.S., Gomez-Sanchez, M.A., Jondeau, G., Klepetko, W., Opitz, C., Peacock, A., Rubin, L., Zellweger, M., \& Simonneau, G.(2009). Guidelines for the diagnosis and treatment of pulmonary hypertension. Eur.Respir.J., Vol.34, No.6, pp. 1219-1263,

Gan, C.T., Lankhaar, J.W., Marcus, J.T., Westerhof, N., Marques, K.M., Bronzwaer, J.G., Boonstra, A., Postmus, P.E., \& Vonk-Noordegraaf, A.(2006). Impaired left ventricular filling due to right-to-left ventricular interaction in patients with pulmonary arterial hypertension. Am.J.Physiol Heart Circ.Physiol, Vol.290, No.4, pp. H1528-H1533,

Gosker, H.R., Wouters, E.F., van der Vusse, G.J., \& Schols, A.M.(2000). Skeletal muscle dysfunction in chronic obstructive pulmonary disease and chronic heart failure: underlying mechanisms and therapy perspectives. Am.J.Clin.Nutr., Vol.71, No.5, pp. 1033-1047,

Groepenhoff, H., Vonk-Noordegraaf, A., Boonstra, A., Spreeuwenberg, M.D., Postmus, P.E., \& Bogaard, H.J.(2008). Exercise testing to estimate survival in pulmonary hypertension. Med Sci Sports Exerc., Vol.40, No.10, pp. 1725-1732, ISSN 1530-0315

Hardziyenka, M., Campian, M.E., Reesink, H.J., Surie, S., Bouma, B.J., Groenink, M., Klemens, C.A., Beekman, L., Remme, C.A., Bresser, P., \& Tan, H.L.(2011). Right ventricular failure following chronic pressure overload is associated with reduction in left ventricular mass evidence for atrophic remodeling. J Am Coll.Cardiol., Vol.57, No.8, pp. 921-928, ISSN 1558-3597

Harrison, R.W., Buehler, W., Thompson, R.G., Long, E.T., Carlson, R., Charbon, B., \& Adams, W.E.(1957). Cardiopulmonary reserve five to fifteen years following fifty per cent or more reduction of lung volume. Surg Forum, Vol.7, pp. 209-213, ISSN 0071-8041

Helbing, W.A., Rebergen, S.A., Maliepaard, C., Hansen, B., Ottenkamp, J., Reiber, J.H., \& de, R.A.(1995). Quantification of right ventricular function with magnetic resonance imaging in children with normal hearts and with congenital heart disease. Am.Heart J., Vol.130, No.4, pp. 828-837,

Hoeper, M.M., Mayer, E., Simonneau, G., \& Rubin, L.J.(2006). Chronic thromboembolic pulmonary hypertension. Circulation, Vol.113, No.16, pp. 2011-2020, ISSN 1524-4539

Holverda, S., Gan, C.T.-J., Marcus, J.T., Postmus, P.E., Boonstra, A., \& Vonk-Noordegraaf, A.(2006). Impaired stroke volume response to exercise in pulmonary arterial hypertension. J Am Coll.Cardiol., Vol.47, No.8, pp. 1732-1733, ISSN 1558-3597

Humbert, M., Sitbon, O., \& Simonneau, G.(2004). Treatment of pulmonary arterial hypertension. N.Engl.J.Med., Vol.351, No.14, pp. 1425-1436,

Hurwit, E.S., Schein, C.J., Rifkin, H., \& Lebendiger, A.(1958). A surgical approach to the problem of chronic pulmonary artery obstruction due to thrombosis or stenosis. Ann.Surg., Vol.147, No.2, pp. 157-165,

Iino, M., Dymarkowski, S., Chaothawee, L., Delcroix, M., \& Bogaert, J.(2008). Time course of reversed cardiac remodeling after pulmonary endarterectomy in patients with 
chronic pulmonary thromboembolism. Eur Radiol., Vol.18, No.4, pp. 792-799, ISSN 0938-7994

Jais, X., Ioos, V., Jardim, C., Sitbon, O., Parent, F., Hamid, A., Fadel, E., Dartevelle, P., Simonneau, G., \& Humbert, M.(2005). Splenectomy and chronic thromboembolic pulmonary hypertension. Thorax, Vol.60, No.12, pp. 1031-1034, ISSN 0040-6376

Jamieson, S.W. \& Kapelanski, D.P.(2000). Pulmonary endarterectomy. Curr Probl.Surg, Vol.37, No.3, pp. 165-252, ISSN 0011-3840

Jamieson, S.W., Kapelanski, D.P., Sakakibara, N., Manecke, G.R., Thistlethwaite, P.A., Kerr, K.M., Channick, R.N., Fedullo, P.F., \& Auger, W.R.(2003). Pulmonary endarterectomy: experience and lessons learned in 1,500 cases. Ann.Thorac.Surg, Vol.76, No.5, pp. 1457-1462, ISSN 0003-4975

Jordan, J., Shannon, J.R., Diedrich, A., Black, B., Costa, F., Robertson, D., \& Biaggioni, I.(2000). Interaction of carbon dioxide and sympathetic nervous system activity in the regulation of cerebral perfusion in humans. Hypertension, Vol.36, No.3, pp. 383388, ISSN 1524-4563

Kasimir, M.T., Seebacher, G., Jaksch, P., Winkler, G., Schmid, K., Marta, G.M., Simon, P., \& Klepetko, W.(2004). Reverse cardiac remodelling in patients with primary pulmonary hypertension after isolated lung transplantation. Eur.J.Cardiothorac.Surg., Vol.26, No.4, pp. 776-781,

Kovacs, G., Berghold, A., Scheidl, S., \& Olschewski, H.(2009). Pulmonary arterial pressure during rest and exercise in healthy subjects: a systematic review. Eur Respir.J, Vol.34, No.4, pp. 888-894, ISSN 1399-3003

Kreitner, K.F., Kunz, R.P., Ley, S., Oberholzer, K., Neeb, D., Gast, K.K., Heussel, C.P., Eberle, B., Mayer, E., Kauczor, H.U., \& Duber, C.(2007). Chronic thromboembolic pulmonary hypertension - assessment by magnetic resonance imaging. Eur Radiol., Vol.17, No.1, pp. 11-21, ISSN 0938-7994

Kreitner, K.F.J., Ley, S., Kauczor, H.U., Mayer, E., Kramm, T., Pitton, M.B., Krummenauer, F., \& Thelen, M.(2004). Chronic thromboembolic pulmonary hypertension: pre- and postoperative assessment with breath-hold MR imaging techniques. Radiology, Vol.232, No.2, pp. 535-543, ISSN 0033-8419

Kyrle, P.A., Minar, E., Hirschl, M., Bialonczyk, C., Stain, M., Schneider, B., Weltermann, A., Speiser, W., Lechner, K., \& Eichinger, S.(2000). High plasma levels of factor VIII and the risk of recurrent venous thromboembolism. N.Engl.J Med, Vol.343, No.7, pp. 457-462, ISSN 0028-4793

Lang, I.(2010). Advances in understanding the pathogenesis of chronic thromboembolic pulmonary hypertension. Br J Haematol., Vol.149, No.4, pp. 478-483, ISSN 1365-2141

Langer, F., Schramm, R., Bauer, M., Tscholl, D., Kunihara, T., \& Schafers, H.J.(2004). Cytokine response to pulmonary thromboendarterectomy. Chest, Vol.126, No.1, pp. 135-141,

Lewczuk, J., Piszko, P., Jagas, J., Porada, A., Wojciak, S., Sobkowicz, B., \& Wrabec, K.(2001). Prognostic factors in medically treated patients with chronic pulmonary embolism. Chest, Vol.119, No.3, pp. 818-823, ISSN 0012-3692

Lim, H.S., Kang, S.J., Choi, J.H., Ahn, S.G., Choi, B.J., Choi, S.Y., Yoon, M.H., Hwang, G.S., Tahk, S.J., \& Shin, J.H.(2009). Is E/E' reliable in patients with regional wall motion abnormalities to estimate left ventricular filling pressure? Int.J.Cardiovasc.Imaging, Vol.25, No.1, pp. 33-39, 
Mainguy, V., Maltais, F., Saey, D., Gagnon, P., Martel, S., Simon, M., \& Provencher, S.(2010). Peripheral muscle dysfunction in idiopathic pulmonary arterial hypertension. Thorax, Vol.65, No.2, pp. 113-117, ISSN 1468-3296

Manning, H.L. \& Schwartzstein, R.M.(1995). Pathophysiology of dyspnea. N.Engl.J Med, Vol.333, No.23, pp. 1547-1553, ISSN 0028-4793

Marcus, J.T., Vonk, N.A., Roeleveld, R.J., Postmus, P.E., Heethaar, R.M., Van Rossum, A.C., \& Boonstra, A.(2001). Impaired left ventricular filling due to right ventricular pressure overload in primary pulmonary hypertension: noninvasive monitoring using MRI. Chest, Vol.119, No.6, pp. 1761-1765,

Mayer, E., Dahm, M., Hake, U., Schmid, F.X., Pitton, M., Kupferwasser, I., Iversen, S., \& Oelert, H.(1996). Mid-term results of pulmonary thromboendarterectomy for chronic thromboembolic pulmonary hypertension. Ann.Thorac.Surg., Vol.61, No.6, pp. 1788-1792,

Menzel, T., Kramm, T., Bruckner, A., Mohr-Kahaly, S., Mayer, E., \& Meyer, J.(2002a). Quantitative assessment of right ventricular volumes in severe chronic thromboembolic pulmonary hypertension using transthoracic three-dimensional echocardiography: changes due to pulmonary thromboendarterectomy. Eur.J.Echocardiogr., Vol.3, No.1, pp. 67-72,

Menzel, T., Kramm, T., Mohr-Kahaly, S., Mayer, E., Oelert, H., \& Meyer, J.(2002b). Assessment of cardiac performance using Tei indices in patients undergoing pulmonary thromboendarterectomy. Ann.Thorac.Surg., Vol.73, No.3, pp. 762-766,

Menzel, T., Wagner, S., Kramm, T., Mohr-Kahaly, S., Mayer, E., Braeuninger, S., \& Meyer, J.(2000). Pathophysiology of impaired right and left ventricular function in chronic embolic pulmonary hypertension: changes after pulmonary thromboendarterectomy. Chest, Vol.118, No.4, pp. 897-903,

Meyer, F.J., Lossnitzer, D., Kristen, A.V., Schoene, A.M., Kubler, W., Katus, H.A., \& Borst, M.M.(2005). Respiratory muscle dysfunction in idiopathic pulmonary arterial hypertension. Eur Respir.J, Vol.25, No.1, pp. 125-130, ISSN 0903-1936

Miyamoto, S., Nagaya, N., Satoh, T., Kyotani, S., Sakamaki, F., Fujita, M., Nakanishi, N., \& Miyatake, K.(2000). Clinical correlates and prognostic significance of six-minute walk test in patients with primary pulmonary hypertension. Comparison with cardiopulmonary exercise testing. Am J Respir.Crit Care Med, Vol.161, No.2 Pt 1, pp. 487-492, ISSN 1073-449X

Moser, K.M., Auger, W.R., \& Fedullo, P.F.(1990). Chronic major-vessel thromboembolic pulmonary hypertension. Circulation, Vol.81, No.6, pp. 1735-1743, ISSN 0009-7322

Moser, K.M. \& Braunwald, N.S.(1973). Successful surgical intervention in severe chronic thromboembolic pulmonary hypertension. Chest, Vol.64, No.1, pp. 29-35, ISSN 0012-3692

O'Donnell, J., Tuddenham, E.G., Manning, R., Kemball-Cook, G., Johnson, D., \& Laffan, M.(1997). High prevalence of elevated factor VIII levels in patients referred for thrombophilia screening: role of increased synthesis and relationship to the acute phase reaction. Thromb.Haemost., Vol.77, No.5, pp. 825-828, ISSN 0340-6245

Palange, P., Ward, S.A., Carlsen, K.H., Casaburi, R., Gallagher, C.G., Gosselink, R., O'Donnell, D.E., Puente-Maestu, L., Schols, A.M., Singh, S., \& Whipp, B.J.(2007). Recommendations on the use of exercise testing in clinical practice. Eur Respir.J, Vol.29, No.1, pp. 185-209, ISSN 0903-1936 
Pengo, V., Lensing, A.W.A., Prins, M.H., Marchiori, A., Davidson, B.L., Tiozzo, F., Albanese, P., Biasiolo, A., Pegoraro, C., Iliceto, S., \& Prandoni, P.(2004). Incidence of chronic thromboembolic pulmonary hypertension after pulmonary embolism. N.Engl.J Med, Vol.350, No.22, pp. 2257-2264, ISSN 1533-4406

Raeside, D.A., Smith, A., Brown, A., Patel, K.R., Madhok, R., Cleland, J., \& Peacock, A.J.(2000). Pulmonary artery pressure measurement during exercise testing in patients with suspected pulmonary hypertension. Eur Respir.J, Vol.16, No.2, pp. 282-287, ISSN 0903-1936

Reesink, H.J., Marcus, J.T., Tulevski, I.I., Jamieson, S., Kloek, J.J., Vonk Noordegraaf, A., \& Bresser, P.(2007a). Reverse right ventricular remodeling after pulmonary endarterectomy in patients with chronic thromboembolic pulmonary hypertension: utility of magnetic resonance imaging to demonstrate restoration of the right ventricle. J Thorac.Cardiovasc.Surg, Vol.133, No.1, pp. 58-64, ISSN 1097-685X

Reesink, H.J., Meijer, R.C., Lutter, R., Boomsma, F., Jansen, H.M., Kloek, J.J., \& Bresser, P.(2006). Hemodynamic and clinical correlates of endothelin-1 in chronic thromboembolic pulmonary hypertension. Circ.J, Vol.70, No.8, pp. 1058-1063, ISSN 1346-9843

Reesink, H.J., Van der Plas, M.N., Verhey, N.E., van Steenwijk, R.P., Kloek, J.J., \& Bresser, P.(2007b). Six-minute walk distance as parameter of functional outcome after pulmonary endarterectomy for chronic thromboembolic pulmonary hypertension. J Thorac.Cardiovasc.Surg, Vol.133, No.2, pp. 510-516, ISSN 1097-685X

Riedel, M., Stanek, V., Widimsky, J., \& Prerovsky, I.(1982). Longterm follow-up of patients with pulmonary thromboembolism. Late prognosis and evolution of hemodynamic and respiratory data. Chest, Vol.81, No.2, pp. 151-158, ISSN 0012-3692

Riley, M.S., Porszasz, J., Engelen, M.P., Brundage, B.H., \& Wasserman, K.(2000). Gas exchange responses to continuous incremental cycle ergometry exercise in primary pulmonary hypertension in humans. Eur.J.Appl.Physiol, Vol.83, No.1, pp. 63-70,

Roul, G., Germain, P., \& Bareiss, P.(1998). Does the 6-minute walk test predict the prognosis in patients with NYHA class II or III chronic heart failure? Am Heart J, Vol.136, No.3, pp. 449-457, ISSN 0002-8703

Rubens, F.D., Bourke, M., Hynes, M., Nicholson, D., Kotrec, M., Boodhwani, M., Ruel, M., Dennie, C.J., \& Mesana, T.(2007). Surgery for chronic thromboembolic pulmonary hypertension--inclusive experience from a national referral center. Ann.Thorac.Surg, Vol.83, No.3, pp. 1075-1081, ISSN 1552-6259

Saxena, N., Rajagopalan, N., Edelman, K., \& Lopez-Candales, A.(2006). Tricuspid annular systolic velocity: a useful measurement in determining right ventricular systolic function regardless of pulmonary artery pressures. Echocardiography., Vol.23, No.9, pp. 750-755,

Smulders, S.A., Holverda, S., Vonk-Noordegraaf, A., van den Bosch, H.C., Post, J.C., Marcus, J.T., Smeenk, F.W., \& Postmus, P.E.(2007). Cardiac function and position more than 5 years after pneumonectomy. Ann.Thorac.Surg., Vol.83, No.6, pp. 1986-1992,

Sun, X.G., Hansen, J.E., Oudiz, R.J., \& Wasserman, K.(2001). Exercise pathophysiology in patients with primary pulmonary hypertension. Circulation, Vol.104, No.4, pp. 429435, ISSN 1524-4539

Surie, S., Bouma, B.J., Bruin-Bon, R.A.H., Hardziyenka, M., Kloek, J.J., Van der Plas, M.N., Reesink, H.J., \& Bresser, P.(2011). Time course of restoration of systolic and 
diastolic right ventricular function after pulmonary endarterectomy for chronic thromboembolic pulmonary hypertension. Am Heart J, Vol.161, No.6, pp. 1046-1052, ISSN 1097-6744

Thistlethwaite PA, Jamieson SW. Invited commentary. (2011) Ann Thorac Surg, Vol.91, No.4 pp. 1100, ISSN21440130.

Tei, C., Dujardin, K.S., Hodge, D.O., Bailey, K.R., McGoon, M.D., Tajik, A.J., \& Seward, S.B.(1996). Doppler echocardiographic index for assessment of global right ventricular function. J.Am.Soc.Echocardiogr., Vol.9, No.6, pp. 838-847,

Unsworth, B., Casula, R.P., Kyriacou, A.A., Yadav, H., Chukwuemeka, A., Cherian, A., Stanbridge, R.L., Athanasiou, T., Mayet, J., \& Francis, D.P.(2010). The right ventricular annular velocity reduction caused by coronary artery bypass graft surgery occurs at the moment of pericardial incision. Am.Heart J., Vol.159, No.2, pp. 314-322,

Van der Plas, M.N., Duffels, M.G., Ponse, D., Mulder, B.J., \& Bresser, P.(2008). Bosentan in mild pulmonary hypertension. Lancet, Vol.372, No.9651, pp. 1730

Van der Plas, M.N., Reesink, H.J., Roos, C.M., van Steenwijk, R.P., Kloek, J.J., \& Bresser, P.(2010). Pulmonary endarterectomy improves dyspnea by the relief of dead space ventilation. Ann.Thorac.Surg, Vol.89, No.2, pp. 347-352, ISSN 1552-6259

Van der Plas, M.N., Surie, S., Reesink, H.J., van Steenwijk, R.P., Kloek, J.J., \& Bresser, P.(2011). Longitudinal follow-up of six-minute walk distance after pulmonary endarterectomy. Ann.Thorac.Surg, Vol.91, No.4, pp. 1094-1099, ISSN 1552-6259

Velez-Roa, S., Ciarka, A., Najem, B., Vachiery, J.L., Naeije, R., \& van de Borne, P.(2004). Increased sympathetic nerve activity in pulmonary artery hypertension. Circulation, Vol.110, No.10, pp. 1308-1312, ISSN 1524-4539

Viner, S.M., Bagg, B.R., Auger, W.R., \& Ford, G.T.(1994). The management of pulmonary hypertension secondary to chronic thromboembolic disease. Prog.Cardiovasc.Dis, Vol.37, No.2, pp. 79-92, ISSN 0033-0620

Vizza, C.D., Lynch, J.P., Ochoa, L.L., Richardson, G., \& Trulock, E.P.(1998). Right and left ventricular dysfunction in patients with severe pulmonary disease. Chest, Vol.113, No.3, pp. 576-583,

Vogel, M., Gutberlet, M., Dittrich, S., Hosten, N., \& Lange, P.E.(1997). Comparison of transthoracic three dimensional echocardiography with magnetic resonance imaging in the assessment of right ventricular volume and mass. Heart, Vol.78, No.2, pp. 127-130,

Wasserman, K., ue, D., tringer, W., hipp, B., \& ansen, J.(2004). Principles of Exercise Testing and Interpretation. No.4th edn., ISSN 7-7817-4876-3

Wensel, R., Opitz, C.F., Anker, S.D., Winkler, J., Hoffken, G., Kleber, F.X., Sharma, R., Hummel, M., Hetzer, R., \& Ewert, R.(2002). Assessment of survival in patients with primary pulmonary hypertension: importance of cardiopulmonary exercise testing. Circulation, Vol.106, No.3, pp. 319-324, ISSN 1524-4539

Wessel, H.U., Kezdi, P., \& Cucell, D.W.(1964). Respiratory and cardiovascular function in patients with severe pulmonary hypertension. Circulation, Vol.29, pp. 825-832,

Wolf, M., Boyer-Neumann, C., Parent, F., Eschwege, V., Jaillet, H., Meyer, D., \& Simonneau, G.(2000). Thrombotic risk factors in pulmonary hypertension. Eur Respir.J, Vol.15, No.2, pp. 395-399, ISSN 0903-1936 
Yasunobo, Y., Oudiz, R.J., \& Sun, X.G.(1999). Dyspnea. Mechanisms, assessment, and management: a consensus statement. American Thoracic Society. Am J Respir.Crit Care Med, Vol.159, No.1, pp. 321-340, ISSN 1073-449X

Yasunobu, Y., Oudiz, R.J., Sun, X.G., Hansen, J.E., \& Wasserman, K.(2005). End-tidal PCO2 abnormality and exercise limitation in patients with primary pulmonary hypertension. Chest, Vol.127, No.5, pp. 1637-1646, ISSN 0012-3692

Zoia, M.C., D'Armini, A.M., Beccaria, M., Corsico, A., Fulgoni, P., Klersy, C., Piovella, F., Vigano, M., \& Cerveri, I.(2002). Mid term effects of pulmonary thromboendarterectomy on clinical and cardiopulmonary function status. Thorax, Vol.57, No.7, pp. 608-612, ISSN 0040-6376 
TOpics w

THORACIC SURGERY

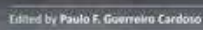

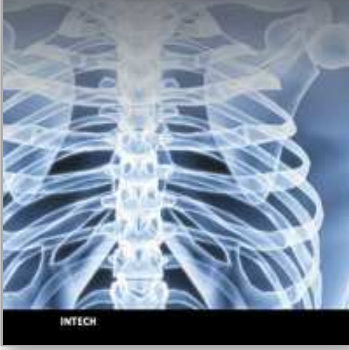

\section{Topics in Thoracic Surgery}

Edited by Prof. Paulo Cardoso

ISBN 978-953-51-0010-2

Hard cover, 486 pages

Publisher InTech

Published online 15, February, 2012

Published in print edition February, 2012

Thoracic Surgery congregates topics and articles from many renowned authors around the world covering several different topics. Unlike the usual textbooks, Thoracic Surgery is a conglomerate of different topics from Pre-operative Assessment, to Pulmonary Resection for Lung Cancer, chest wall procedures, lung cancer topics featuring aspects of VATS major pulmonary resections along with traditional topics such as Pancoast tumors and recurrence patterns of stage I lung disease, hyperhidrosis, bronchiectasis, lung transplantation and much more. This Open Access format is a novel method of sharing thoracic surgical information provided by authors worldwide and it is made accessible to everyone in an expedite way and with an excellent publishing quality.

\section{How to reference}

In order to correctly reference this scholarly work, feel free to copy and paste the following:

Coen van Kan, Mart N. van der Plas, Jaap J. Kloek, Herre J. Reesink and Paul Bresser (2012). Chronic Thromboembolic Pulmonary Hypertension: Effects of Pulmonary Endarterectomy, Topics in Thoracic Surgery, Prof. Paulo Cardoso (Ed.), ISBN: 978-953-51-0010-2, InTech, Available from:

http://www.intechopen.com/books/topics-in-thoracic-surgery/chronic-thromboembolic-pulmonary-hypertensioneffects-of-pulmonary-endarterectomy

\section{INTECH}

open science | open minds

\author{
InTech Europe \\ University Campus STeP Ri \\ Slavka Krautzeka 83/A \\ 51000 Rijeka, Croatia \\ Phone: +385 (51) 770447 \\ Fax: +385 (51) 686166 \\ www.intechopen.com
}

\author{
InTech China \\ Unit 405, Office Block, Hotel Equatorial Shanghai \\ No.65, Yan An Road (West), Shanghai, 200040, China \\ 中国上海市延安西路65号上海国际贵都大饭店办公楼 405 单元 \\ Phone: +86-21-62489820 \\ Fax: +86-21-62489821
}


(C) 2012 The Author(s). Licensee IntechOpen. This is an open access article distributed under the terms of the Creative Commons Attribution 3.0 License, which permits unrestricted use, distribution, and reproduction in any medium, provided the original work is properly cited. 